\title{
COLORADOSCHOOLOFMINES
}

EARTH•ENERGY•ENVIRONMENT

DIVISION OF ECONOMICS AND BUSINESS

WORKING PAPER SERIES

\section{Did California's hand-held cell phone ban reduce accidents?}

Nicholas E. Burger

Daniel T. Kaffine

$\mathrm{Bo} \mathrm{Yu}$

\author{
Working Paper 2013-08 \\ http://econbus.mines.edu/working-papers/wp201308.pdf \\ Colorado School of Mines \\ Division of Economics and Business \\ 1500 Illinois Street \\ Golden, CO 80401
}

August 2013

(c) 2013 by the listed authors. All rights reserved. 
Colorado School of Mines

Division of Economics and Business

Working Paper No. 2013-08

August 2013

Title:

Did California's hand-held cell phone ban reduce accidents?

Author(s):

Nicholas E. Burger

RAND

Washington, D.C., USA

Daniel T. Kaffine

Division of Economics and Business

Colorado School of Mines

Golden, CO 80401-1887

$+13033842430$

dkaffine@mines.edu

Bo $\mathrm{Yu}$

Division of Mathematics and Computer Science

Colorado School of Mines

Golden, CO 80401-1887

\begin{abstract}
On July 1st, 2008, California enacted a ban on hand-held cell phone use while driving. Using California Highway Patrol panel accident data for California freeways from January 1st, 2008 to December 31st, 2008, we examine whether this policy reduced the number of accidents on California highways. To control for unobserved time-varying effects that could be correlated with the ban, we use high-frequency data and a regression discontinuity design. We find no evidence that the ban on hand-held cell phone use led to a reduction in traffic accidents.
\end{abstract}

Keywords: Cell phone ban, traffic safety, regression discontinuity 


\section{Introduction}

It has become conventional wisdom that cell phone use leads to poor driving. Of particular concern is the perception that cell phone use distracts drivers and causes them to get into accidents. One often cited study by Redelmeier and Tibshirani (1997) found that using a cell phone increased an individual's accident risk by 4.5 times.

Dramatic numbers such as these have led traffic safety advocates to call for bans on cell phone use while driving. By contrast, based on survey data, economists Hahn and Prieger (2006) find weak evidence for a reduction in accidents due to a cell phone-use ban (handheld or hands-free) after controlling for selection bias and heterogeneous risk across drivers. Their central estimate is a 1.5 percent decrease in accidents with standard errors large enough to include a zero effect. This stands in contrast to previous studies (reviewed and critiqued in Hahn and Dudley (2002)) which found evidence that a ban would significantly reduce accidents. In particular, based on Redelmeier and Tibshirani (1997), estimates by Redelmeier and Weinstein (1999) suggest a two percent reduction in accidents from a ban, while Cohen and Graham (2003) calculate a two to 21 percent reduction in accidents with a central estimate of a six percent reduction.

There is no question that cell phone use has increased significantly in the past two decades. Hahn and Prieger (2006) report that in December 2004, there were 182 million subscribers in the United States. By June 2008, that number had grown to 268 million (a penetration of 86.1 percent), which is nearly double the number of subscribers reported in Cohen and Graham (2003). ${ }^{1} \quad$ In light of this massive growth in cell phone usage and concern about

\footnotetext{
${ }^{1}$ From http://www.cellular-news.com/story/33578.php.
} 
their safety while used when driving, we build upon previous research on the effects of a cell phone ban while moving beyond the epidemiological, survey, and field test designs typically employed in earlier studies. $^{2}$

On July 1st, 2008, California enacted a ban on hand-held cell phone use while driving (hereafter, "cell phone ban"). ${ }^{3}$ In this study, we test whether the ban reduced accidents in the state of California. One reason our analysis is distinct from other studies is that it is based on high-frequency vehicle accident data around the time the cell phone ban was enacted. Using daily accidents on major freeways and highways in nine of California's traffic districts, we analyze the impact of the ban on accidents. We utilize a regression discontinuity designsimilar to Davis (2008) — to control for unobserved covariates that can confound traditional regression analysis.

Across various specifications, we find no evidence of a reduction in accidents state-wide due to the ban. One important caveat worth mentioning is that we are unable to separate the effect of compliance from an effect of cell phone use on accidents. In other words, while we find that accidents did not decrease due to the cell phone ban, we are unable to say if the lack of an effect is because cell phone use does not affect accidents, because drivers substituted to other disruptive-but legal-hands-free or text messaging technologies, or because weak compliance failed to reduce cell phone use. Nor can we determine if increased enforcement efforts designed to raise compliance levels would lead to a reduction in accidents. ${ }^{4}$ Nonetheless, this study provides evidence that the California policy failed to achieve its objective of

\footnotetext{
${ }^{2}$ See Lissy et al. (2000) and Hahn and Dudley (2002) for further review and critique of these studies.

${ }^{3}$ It is important to note that hands-free devices were still allowed.

${ }^{4}$ For example, a "click-it-or-ticket" type policy designed to promote public awareness and promise enhanced enforcement.
} 
reducing traffic accidents.

We proceed by first discussing previous studies on cell phone and accident risk and provide an overview of California's ban. We next discuss the data used in our study, the empirical models used for estimation, and our results.

\section{Cell phone use and road safety}

There is a long history of concern over the effect of drivers' in-car activities on automotive incidents. ${ }^{5}$ Driver actions believed to increase accident risk include using the radio, conversing with passengers, or talking on a mobile phone. Concern about the negative effects of cell phone use while driving has grown in recent years due to fears that cell phone use has increased the number of vehicle accidents and roadway fatalities.

Given the significant increase in cell phone use and subsequent health and safety concerns, it is not surprising that the issue of cell phone use by drivers has received considerable attention by researchers. One set of studies has used driving simulators in laboratory settings to explore the effects of cell phone use while driving. The evidence from driving simulators generally shows that cell phone use adversely affects driving. Strayer and Johnston (2001) demonstrate that drivers talking on a cell phone are more likely to miss traffic cues or respond with delay, and later work shows that these effects are not limited to hand-held cell phone operation (Strayer et al., 2003). Specifically, these studies showed that hands-free cell phone operators were just as likely to create accident risks as hand-held cell phone operators. Strayer et al. (2006) characterize the relative impact of driving while talking on the phone

\footnotetext{
${ }^{5}$ Frequently, we use the terms "incident" and "accident" interchangeably, while recognizing that some readers may not consider them synonymous.
} 
and find that driver impairment is roughly equivalent to driving while intoxicated. While these studies take a scientific approach to controlling environmental conditions, they may be of limited policy relevance if, for example, drivers behave differently in a simulator than on the road; ${ }^{6}$ moreover, this type of research provides little information about whether government regulation can effectively mitigate risks.

There have also been various attempts to use survey data to estimate the effect of banning hand-held cell phone use on accident frequency. Estimates by Redelmeier and Weinstein (1999), based on Redelmeier and Tibshirani (1997), suggest a two percent reduction in accidents from a ban, while Cohen and Graham (2003) calculate a between two and 21 percent reduction in accidents with a central estimate of six percent. However, these studies are based on methods (case-crossover) that potentially overestimate the benefits of reducing driver cell phone use due to selection bias. Kolko (2009) also uses survey data on the number of cell phone users by state in a panel data framework and find that cell phone bans reduce the number of accident-related fatalities in adverse weather conditions and during rush hour but have little effect on overall fatalities.

Others, such as Hahn and Prieger (2006), find weak evidence for a reduction in accidents due to a cell phone use ban after controlling for selection bias and heterogeneous risk across drivers. In contrast to previous observational research, their central estimate from survey data is a 1.5 percent decrease in accidents due to a ban with standard errors large enough to include a zero effect. In a related survey study, Hahn and Prieger (2007) find that drivers who use cell phones while driving are more likely to be involved in accidents, even when

\footnotetext{
${ }^{6}$ This could be due to dramatically different incentives across these environments or Hawthorne effects.
} 
not using a phone, suggesting that omitted variable bias may be driving previous results. If drivers' underlying attitudes towards safety lead to both cell phone use and accidents, then reducing cell phone use may be ineffective. After correcting for this endogeneity, Hahn and Prieger (2007) find no evidence of an increase in accidents due to hand-held or hands-free cell phone use.

Nevertheless, estimating a cell phone ban's theoretical effectiveness and measuring actual effectiveness will not necessarily produce the same results. Two recent studies evaluate the effect of cell phone ban policy using collision data. Highway Loss Data Institute (2009) analyze state level automobile insurance claim frequencies (including California) using a difference-in-differences method. Using neighboring states as a control group, they find no evidence that insurance claim frequencies decreased due to bans on cell phone use. Nikolaev et al. (2010) compare county-level accidents in New York pre-ban (1997-2001) and postban (2002-2007) and find some evidence of a decrease in accidents in the post-ban period. However, as the authors note, they are unable to distinguish between decreases in accidents due to the cell phone ban, and decreases in accidents due to other causes. As noted in Highway Loss Data Institute (2009), collision frequencies in control states were also declining during this time period, which would confound estimates of the effect of the policy.

In this paper we estimate whether California's cell phone ban reduced roadway accidents using observed daily accidents on major California freeways. By utilizing a regression discontinuity method, we control for confounding unobservables that can affect accident rates, allowing us to identify the causal effect of the cell phone ban. 


\subsection{State responses to safety concerns}

Despite limited and conflicting evidence over whether cell phone use increases accidents on roadways, several states (and the District of Columbia) have implemented full or partial bans on cell phone by motor vehicle drivers. As of November 2011, nine states had state-wide bans on hand-held cell phone use while driving, and several states had bans that varied by within-state jurisdiction. Some states have also banned other cell phone related activities, including text messaging. ${ }^{7} \quad$ No state, however, currently bans all types of cell phone use (hand-held and hands-free) by all drivers. Enforcement also varies by state, with some states allowing law enforcement officers to pull over a driver solely for talking on a hand-held phone (primary enforcement), while others require an officer to have some other reason for making a traffic stop (secondary enforcement).

There are a number of reasons that state bans may not be effective at reducing accidents. If the act of talking on a cell phone - not the method of talking (hand-held versus handsfree) - increases accident probability, then forcing drivers to shift from one method to another would only reduce accidents to the extent that some drivers opted to not use their cell phone rather than purchase a hands-free device. ${ }^{8} \quad$ Furthermore, the type of driver who may be distracted by their cell phone to the point of being accident-prone may be an inherently careless driver who simply does not take traffic safety seriously, per Hahn and Prieger (2007).

${ }^{7}$ The nine states with hand-held cell phone bans are California, Connecticut, Delaware, Maryland, Oregon, Nevada, New York, New Jersey, and Washington, as well as the District of Columbia. For more information on the details of state bans, see http://www.ghsa.org/html/stateinfo/laws/cellphone_laws.html. A total of 35 states and the District of Columbia have banned text messaging while driving. Several dozen countries have also banned the use of hand-held cell phones while driving.

${ }^{8}$ While Strayer et al. (2003) found no difference in hand-held and hands-free drivers, a recent study by Kolko (2009) does find that requiring hands-free use does reduce accidents, though only in inclement weather. 
In addition, fines for violating the laws can be as low as $\$ 20$ per violation. Moreover, tickets typically do not add "points" to a driver's record, and many insurance companies do not condition rates on cell phone ban violations. Thus the cost of violating a ban may be limited. Weak enforcement may also limit the laws' effectiveness. Small fines coupled with a low probability of enforcement may not provide much incentive for driver compliance. Finally, bans may be ineffective if drivers inclined towards noncompliance with the law are precisely those drivers most inclined towards accident-prone driving.

\subsection{California's hand-held cell phone ban}

In 2006, the Governor of California signed into law a ban on hand-held cellular phone use while driving. The law (Vehicle Code 23123) was motivated primarily by concerns over road safety and designed to reduce the number of accidents related to cell phone use while driving. The law banned hand-held cell phone use by all California drivers while operating most types of passenger and commercial vehicles. Adult drivers are allowed to use a hands-free device while driving; for drivers under age 18 the law banned all cell phone use, hand-held or handsfree. $^{9}$ The ban went into effect on July 1, 2008 statewide, and there was no official grace period for enforcement after the ban went into effect.

The penalty for violating the cell phone ban the first time is a $\$ 20$ fine, while subsequent convictions are punishable by a $\$ 50$ fine or more. ${ }^{10}$ Drivers do not, however, receive "points" on their license if caught violating the law. There is no penalty for talking on a cell phone as long as the driver is using either a hands-free device (typically a bluetooth earpiece) or using

\footnotetext{
9 The law includes other exemptions, including allowing emergency calls while driving and use by certain commercial drivers.

${ }^{10}$ Penalty assessments can increase the effective fine to more than triple the base amount.
} 
the speakerphone function of their phone. This particular law did not ban text messaging, though a separate regulation (Vehicle Code 23123.5), effective January 1, 2009, prohibits motorists from any text messaging activities while driving.

\section{Measuring Accidents Across California}

Our approach utilizes daily aggregated traffic accident data, with the cell phone ban serving as a quasi-natural experiment. We collect data on accidents that occurred on major highways throughout the state of California during a six-month window on either side of the state's cell phone ban, from January 1, 2008 to December 31st, 2008. This period was chosen because it is the longest symmetric period surrounding July 1, 2008, that does not overlap with the additional ban on text messaging that went into effect on January 1, 2009.

Our data set includes over 500,000 highway incidents, including vehicular collisions, that occurred on California highways in 2008 as reported by the California Highway Patrol (CHP) to the Performance Management System (PeMS). PeMS collects, manages, and publishes data on California highway conditions. The accident data includes the location of each incident (by district, highway, and mile marker), the date and time the accident occurred, the duration of the incident, and the type of incident (for example, non-injury accident, injury accident, vehicle debris, stalled car, animals in the roadway). We aggregate the incident data into total daily accidents and "hazards" by type by district. ${ }^{11}$ Accidents include all forms

${ }^{11}$ Three of California's traffic districts are very sparsely populated and see only one or two incidents per day (if any) and we have excluded them from the analysis. These three districts (numbers 1,2,9) constitute a tiny portion of California's population and their exclusion is unlikely to influence our results. For a point of comparison, more accidents occur on two average days in District 7 (Los Angeles and Ventura counties) than in District 9 over the entire year. 
of collisions and hit-and-runs, while hazards include non-collision incidents, such as debris in the roadway or stalled cars.

In addition to the accident data, we also collected rainfall data for each district. These data correspond to daily precipitation measured at the central city (in Table 1) and were taken from the National Weather Service. ${ }^{12}$ Average weekly gas price in California was collected from the Energy Information Administration. ${ }^{13}$

We provide summary statistics in Table 1 . Total accidents per day range from a low of five to high of 719. The mean number of accidents per day ranges from a low of 21 in district 10, which includes the city of Stockton, to a high of 210 in district 7 which covers most of Los Angeles. ${ }^{14}$ Table 2 reports the pre-ban and post-ban means for collisions, hazards, rainfall, and gasoline prices. The mean number of accidents statewide fell by a statistically insignificant amount after the ban went into effect $(p=0.50)$, although changes at the district level were more heterogeneous. ${ }^{15}$ The change in mean hazards was not significant either, though both mean rainfall $(p=0.001)$ and mean gasoline prices $(p=0.000)$ fell in the second half of the year, following the cell phone ban.

\footnotetext{
12 See http://www.weather.gov/climate/index.php.

13 The data can be found at http://www.eia.doe.gov/oil_gas/petroleum/info glance/petroleum.html

14 There was one day in which zero accidents were reported for all but one district, July 16, which appears to be a problem with reporting. The gap in reporting also partially extends into neighboring days. We have excluded these days from the analysis below.

15 Comparing mean accidents between the first and second halves of 2007 finds a similar statistically insignificant difference.
} 


\section{The Effect of California's Cell Phone Ban}

In this section we report our estimates of the effect of California's cell phone ban on the number of daily accidents. We employ three basic strategies to control for unobserved time varying covariates that could bias estimates of the policy's effect. In the first specification we estimate a basic linear reduced-form model as follows:

$$
A c c_{i t}=\alpha+\beta \operatorname{Ban}_{t}+\gamma_{1} R_{i t}+\gamma_{2} R_{i t}^{2}+\delta H_{t}+\zeta P_{t}+F_{i}+D_{t}+\epsilon_{i t}
$$

where $\beta$ is our coefficient of interest, and corresponds to the marginal effect of the handheld cell phone ban on accidents $\left(\operatorname{Ban}_{t}=0\right.$ before July 1st, 2008, and $\operatorname{Ban}_{t}=1$ from July 1st onward). Note that the coefficient $\beta$ can be interpreted at the difference in the conditional means pre- and post-policy. District-specific rainfall totals $\left(R_{i t}\right)$, gas prices $\left(P_{t}\right)$, day dummies $\left(D_{t}\right)$, controls for federal holidays $\left(H_{t}\right)$, and district fixed effects $\left(F_{i}\right)$ are also included. Using this basic model framework, we narrow the estimated time period on either side of the policy date to limit the possible influence of other time-varying factors, though at the cost of fewer observations.

Next, we consider a regression discontinuity design (RD) to address the problem of unobserved time-varying factors. RD methods are often used to estimate treatment effects in cross-sectional data when treatment assignment can be considered randomized around a particular threshold (Lee and Lemieux, 2010). Here we follow an approach similar to Davis (2008) and apply the RD methodology to panel data where time serves as the treatment assignment variable. We consider two different approaches. In the first, we add a flexible 
global n-th order polynomial time trend $g(t)$ to equation $1:^{16}$

$$
A c c_{i t}=\alpha+\beta \operatorname{Ban}_{t}+g(t)+\gamma x_{t}+\epsilon_{i t}
$$

where the additional control variables from equation 1 have been collapsed into $x_{t}$. As long as $g(t)$ is continuous at the policy date, $\beta$ will correspond to the magnitude of the discontinuity in accidents at the policy date. Intuitively, the function $g(t)$ will control for unobserved factors that evolved smoothly over time and are unrelated to the cell phone ban. In the results presented below, we provide estimations incorporating first- through third-order polynomials.

In addition to the global polynomial, we also consider a local linear regression discontinuity design with various kernel and bandwidths (Imbens and Lemieux, 2008). ${ }^{17}$ We vary bandwidths from three months (50 percent of our data) to two months (33 percent of our data) to one month (17 percent of our data), with separate linear trends fit on either side of the policy date. Provided that the conditional expectation of all other variables affecting accidents is continuous at the discontinuity point, the coefficient $\beta$ will identify the treatment effect of the hand-held cell phone ban (Hahn et al., 2001). In other words, no other discontinuous changes can occur at that policy date that would confound our estimate of the policy impact. Figure 1 provides evidence that other accident-related variables do not show discontinuous jumps when the policy was implemented. We also include in Figure 1 plots of ${ }^{16}$ Davis (2008) adopts a similar approach when looking at the impact of driving restrictions in Mexico City on a time-series of pollution readings. See Imbens and Lemieux (2008) for a discussion of regression discontinuity design.

${ }^{17}$ Carpenter and Dobkin (2009) utilize both the global polynomial approach and the local linear regression method in their regression discontinuity estimates of the impact of alcohol consumption on mortality. 
the raw accidents and hazards data, averaged across the state and by week. Notably, there are no obvious difference in accidents before and after the policy date. In addition to the coefficient estimates in the tables presented below, we also present figures that allow us to check the fit of the regression model.

\subsection{Effect of California's hand-held cell phone ban}

We begin with a panel estimation of the effects of the cell phone ban. For each of the three approaches discussed above, we estimate accidents with a count model (negative binomial). ${ }^{18}$ The first three columns of Table 3 present regression estimates under the "windowed" approach. The six month (January 1st-December 31st, 2008), three month (April 1st-September 31st) and one month (June 1st-July 31st) windows find no evidence of a reduction in accidents. Narrowing the time window has little impact on the estimates, which range from -1 percent to +1 percent. $^{19}$

However, this null result could arise from unobserved variables unrelated to the policybut correlated with time - that cancel out any policy effect. ${ }^{20}$ For example, macro-economic trends over this time period that increased vehicle miles traveled (VMT) could result in more accidents, countervailing the effect of the policy. To further address the issue of unobserv-

${ }^{18}$ All results presented below were also estimated with a linear model using a logged dependent variable with no discernable differences. Additionally, the negative binomial model with fixed effects should, if anything, provide underestimates of the standard errors (Allison and Waterman, 2002).

19 The coefficients on the policy variables are transformed into marginal percentage effects according to $100 *\left(e^{\beta}-1\right)$.

${ }^{20}$ For example, if the ban decreased accidents but was offset by an unrelated increase in accidents in the latter months of the year. Restricting the window to just one month on either side of the policy date makes this possibility rather unlikely, at the cost of substantial data loss. The global regression discontinuity methods discussed below allow for the full use of the dataset. 
ables, we consider a regression discontinuity design. The estimates presented in the final three columns of Table 3 incorporate a flexible time trend to control for time-varying unobservables. Again, there is little evidence of a decrease in accidents attributable to the cell phone ban, with point estimates ranging from 0 percent to +4 percent.

Large $R^{2}$ and pseudo- $R^{2}$ for these regressions (over 0.80 for all regressions), leave surprisingly little variance left unexplained. Nonetheless, to ensure that the other model covariates are behaving appropriately, we consider the coefficients on rainfall, gas price, and the indicator variables for weekday holidays reported in Table 3. Due to the short time window, we exclude column three from the discussion below. ${ }^{21}$ Rainfall coefficients are significant across specifications and suggest an increasing, concave impact on accidents. This concavity may be due to people driving less when rainfall becomes excessively heavy and driving conditions worsen. Estimates of the impact of gasoline price are negative and significant across all specifications, except the narrow time window specification in column 3. This is likely driven by the fact that VMT falls as gasoline prices increase, leading to fewer accidents. ${ }^{22}$ The holiday coefficient is negative and significant, with 13 percent to 15 percent fewer accidents occurring on holidays. ${ }^{23}$

One disadvantage of the global polynomial method, noted by Imbens and Lemieux (2008),

${ }^{21}$ While the very short time window is useful for identifying the effect of the cell phone ban on accidents, coefficient estimates for other covariates are less informative - for example, of the 504 district-day observations, only 4 report (trivial) amounts of rainfall, and the Fourth of July is the only Federal Holiday during this time window.

${ }^{22}$ This result is consistent with Grabowski and Morrisey (2004) who find motor vehicle fatalities fall as gasoline prices rise.

${ }^{23}$ While not reported, the day-of-week dummies are significant relative to the omitted Sunday dummy, with 20 percent more accidents on Mondays, Tuesdays, Wednesdays and Saturdays, over 30 percent more accidents on Thursdays and over 50 percent more accidents on Fridays. 
is that estimates are sensitive to observations far from the policy date. To address this concern, we present local linear regression estimates in Table 4. This table includes estimates for bandwidths of six months, three months, two months and one month, with rectangular, triangular, Epanechikov, and Gaussian kernels. Again, there is no evidence of an effect of the policy, with insignificant estimates ranging from -3 percent to +2 percent.

Because we are using panel data with a relatively large time dimension, serial correlation is a possible concern. However, because each observation is an entire day, it is somewhat unlikely that accidents on day $t$ affect accidents on day $t+1$. Nevertheless, we estimate a set of alternative specifications (results available upon request) to allow for autocorrelation across observations. ${ }^{24}$ In all cases, the results from these robustness checks were consistent with the those described above, with consistently larger standard errors and no evidence of a significant policy effect.

Although the policy went into effect on July 1, drivers may have anticipated the policy and preemptively complied, or individual compliance may have lagged due to habit formation or lack of information about the ban. In Table 5 we assess whether our results are sensitive to observations around the ban date, due to drivers anticipating the cell phone ban or delaying their response to it. We remove three-week sections of data centered on the ban date, immediately prior to the ban, and immediately following the ban, which will sharpen any

\footnotetext{
${ }^{24}$ Specifically, we estimate a model with standard errors clustered at the district level, which allows for an arbitrary error correlation structure within districts. Our data may not satisfy the asymptotic properties of the cluster estimator, however, because we have only nine groups. Consequently, we also estimated Driscoll-Kraay standard errors, which allow for arbitrary autocorrelation and heteroscedasticity in unbalanced panels. As noted in the text, in both cases the standard error on the policy variables was larger than in the results reported in Table 3, reducing the significance of the coefficient estimates and confirming that the policy had no effect on accidents.
} 
discontinuous change in accidents due to the cell phone ban. The columns of Table 5 repeat the above analysis with different time trends, mirroring Table 3. Consistent with the previous estimations, there is no evidence that accidents decreased following the implementation of the cell phone ban, which suggests that our results are not sensitive to observations near the date the ban was implemented.

As an additional robustness check, we also examine roadway hazards. Hazards are roadway incidents, such as stalled cars and debris on the roadway, that should not be related to cell phone use; however, they are likely correlated with the root causes of travel demand, including potentially unobservable factors. If travel demand affects both accidents and hazards, then running the above estimations with hazard data could identify unobserved trends we are not able to capture in our accident analysis. For example, a discontinuous increase in travel demand that occurred at the same time as the enactment of the ban would invalidate our identification strategy - the hand-held ban may have reduced traffic accidents, but estimates would be confounded by increased accidents due to higher travel demand. If such a coincidental increase in travel demand occurred, this would manifest itself in the form of a discontinuous increase in traffic hazards at the policy date. Results (available upon request) from estimations using hazards in place of accidents found no evidence of a discontinuous change in hazards on July 1st, suggesting the effect of the cell phone ban on accidents is properly identified in the results discussed above. ${ }^{25}$

Finally, we illustrate the regression discontinuity methodology and the fit of our regression estimates in Figure 2. We plot the residuals - aggregated by day across districts - from

${ }^{25}$ We considered using accident data from 2007 as a 'control' for accidents in 2008. However, due to the significant macroeconomic differences between the two years, particularly in the housing market, it is unlikely that 2007 would serve as an appropriate control for 2008. 
estimating equation 1 without Ban. We then overlay the four time trends and ban intercepts on the residuals. These residuals represent the unexplained variation in accidents, and thus should reveal any discontinuous effect of the hand-held cell phone ban as well as any unobserved trends over time. The discontinuities in Figure 2 are consistent with the estimates from Table 3, namely that there is no discernable change in accidents following the hand-held cell phone ban.

As a final note, while Table 5 examined the sensitivity of our results around the policy date, it is possible that either anticipatory behavior or learning behavior existed at longer time scales. It is not immediately clear why drivers who had revealed a preference for handheld phone use would adopt a costly and cumbersome alternative technology before the handheld ban was binding. Nonetheless, if such anticipatory behavior occurred in the months preceding the ban, this would manifest itself in the residual plots in Figure 2 as a change in the accident trend pre-ban. Visual inspection of the residuals finds little evidence to suggest a broad change in accidents before the policy became active. In terms of learning behavior post-ban, one might imagine two types of responses. First, drivers may have learned about enforcement effort and adjusted their phone usage while driving accordingly, and second, drivers may become more skilled with hands-free operation. If this behavior occurred, this would again appear in the residual plots of Figure 2 as a change in accident trend post-ban. Again, visual inspection of the residuals finds little evidence to suggest a change in accident trend in the months following the implementation of the hand-held ban. ${ }^{26}$

\footnotetext{
${ }^{26}$ Formally, learning behavior resulting from the policy would manifest itself as a change in the slope of the accident trend post-ban, as opposed to an intercept-shift at the policy date as estimated in equations 1 and 2. Estimates allowing a change in the post-ban trend (an interaction term $\mathrm{Ban}_{t} \cdot t$ ) were performed, and they confirm the results of the visual inspection of the residuals in Figure 2 - the change in the accident trend in the months
} 


\subsection{Discussion}

We find little evidence of a decrease in accidents due to the California cell phone ban. The simplest explanation for this result is that drivers are not complying with the law. Unfortunately, we have no systematic data on cell phone ban compliance rates, and we are unable to directly observe cell phone usage while driving. Nevertheless, if drivers are four times more likely to cause accidents on cell phones (per Redelmeier and Weinstein (1999)) and are just as impaired as drunk drivers (per Strayer et al. (2006)), even modest compliance by the more than 77 percent of Californians that own cell phones would likely show a detectable decrease in accidents. ${ }^{27} 28$

Even if drivers fully complied with the law, it is possible that accidents would not decrease. First, if hands-free cell phone use is as distracting as hand-held use (Strayer et al., 2003), substitution from one method to the other may leave the number of accidents unchanged. ${ }^{29}$ Or, as Hahn and Prieger (2006) and Hahn and Prieger (2007) suggest, risk may vary across drivers, and drivers who use cell phones may simply be inherently more careless and accident prone. In this case, if the marginal effect of cell phone use for risky drivers is small, then the ban would have little effect on outcomes. Again, we lack the data to estimate these effects.

following the policy implementation was statistically insignificant.

${ }^{27}$ Cell phone penetration rates are drawn from Kolko (2009) and are for 2005.

${ }^{28}$ The L.A. Times reported on January 3rd, 2009, that 48,000 tickets were written by the California Highway Patrol, which does not include tickets issued by county and city law enforcement officers. Santa Monica Police Sgt. Larry Horn claims: "Six months ago, everywhere I looked someone who was driving was on the phone... From the saddle, I'm seeing less people on the phone now." At http://articles.latimes.com/2009/jan/03/local/mehandsfree3.

${ }^{29}$ In many cases, drivers using hand-free devices must still dial the phone manually, which often requires taking one's eyes off the road. Moreover, switching technologies from handheld to hands-free may temporarily increase the adverse effects of cell phone use on driving due to learning. 
In the absence of good compliance data and detailed usage data for drivers, we are agnostic on whether our results are driven more by compliance issues, substitution towards equally distracting hands-free use, or Hahn and Prieger's "careless driver" findings. Further research into this issue may be useful to disentangle these effects and help guide public policy on cell phone use. For example, if compliance is the issue, increasing fines may be sufficient to lower accident rates. On the other hand, if both cell phone use and accidents are a function of an unobserved variable "risk-prone behavior" (per Hahn and Prieger (2007)), other approaches may be needed. In any case, our results suggest that the California cell phone ban did not achieve the reduction in accidents that proponents hoped for - this policy, as implemented, was ineffective.

We also note that while we find no evidence that California's cell phone ban reduced overall accidents, it is possible that a subset of accidents - for example, fatal accidentsdecreased due to the policy, but constitute too small of a fraction of overall accidents to show up in the aggregate estimates. Another way of stating this is that if the ban reduced cell phone use while driving and if cell phone use affects the severity, but not frequency, of accidents, then fatalities could fall even as accident rates remain the same. This outcome, if valid, would be consistent with Kolko (2009). However, we do not have evidence for or against this conclusion.

Finally, we note that our results are consistent with the difference-in-differences estimates reported in Highway Loss Data Institute (2009), which found no evidence of a reduction in insurance claims due to cell phone bans in several states. By contrast, Nikolaev et al. (2010) find evidence of accident reductions due to New York's cell phone ban. Our differing results may be explained by differences in enforcement and compliance in New York versus 
California, or because, as the authors note, they did not control for changes in accident frequency unrelated to the cell phone ban over their 10-year window of study.

\section{Conclusions}

We present evidence from observed accidents in California over a period in which the state implemented a law to ban hand-held cell phone use while driving a motor vehicle. In contrast to much of the previous research in this area, we treat the implementation of the policy as a quasi-natural experiment and draw on empirical data to determine whether mean daily accidents fell after California implemented the ban. To control for unobserved time-varying effects that could be correlated with the policy, we employ three regression discontinuity strategies: narrowing the time window of analysis, using a highly flexible global polynomial, and using a local linear regression design. The $\mathrm{RD}$ approach has advantages over previous empirical work on this topic, namely that we avoid using cross-sectional panel data that are likely susceptible to significant unobserved heterogeneity and omitted factors. We find no evidence of a state-wide decrease in accidents as a result of the ban. While our results are specific to California, cell phone bans in other jurisdictions that have similar enforcement and penalty parameters could be expected to have similar effects.

While this non-result may seem surprising to people accustomed to seeing drivers using cell phones doing careless or dangerous things on the highway, drivers were doing careless and dangerous things on highways long before the invention of the cell phone. Given the high costs imposed on society by accidents, it is important to have empirical evidence detailing which policies are effective in reducing accidents. Our findings highlight the need for more 
research on the "in the field" effects of cell phone bans, including research on the effect of penalty strength or enforcement on accidents.

\section{References}

Allison, P. D. and R. P. Waterman (2002). Fixed effects negative binomial regression models. Sociological Methodology 32, 247-265.

Carpenter, C. and C. Dobkin (2009). The effect of alcohol consumption on mortality: Regression discontinuity evidence from the minimum drinking age. American Economic Journal: Applied Economics 1(1), 164-182.

Cohen, J. T. and J. D. Graham (2003). A revised economic analysis of restrictions on the use of cell phones while driving. Risk Analysis 23(1), 5-17.

Davis, L. (2008). The effect of driving restrictions on air quality in mexico city. Journal of Political Economy 116(1), 38-81.

Grabowski, D. C. and M. A. Morrisey (2004). Gasoline prices and motor vehicle fatalities. Journal of Policy Analysis and Management 23(3), 575-593.

Hahn, J., P. Todd, and W. Van der Klaauw (2001). Identification and estimation of treatment effects with a regression discontinuity design. Econometrica 69, 201-209.

Hahn, R. W. and P. M. Dudley (2002). The disconnect between law and policy analysis: A case study of drivers and cell phones. Administrative Law Review 55(1), 127-185.

Hahn, R. W. and J. E. Prieger (2006). The impact of driver cell phone use on accidents. The B.E. Journal of Economic Analysis 8 Policy 6 (1 Advances).

Hahn, R. W. and J. E. Prieger (2007). Are drivers who use cell phones inherently less safe? Applied Economics Quarterly 53(4), 327-352.

Highway Loss Data Institute (2009). Hand-held cellphone laws and collision claim frequencies. HLDI Bulletin 26(17).

Imbens, G. W. and T. Lemieux (2008). Regression discontinuity designs: A guide to practice. Journal of Econometrics 142, 615-635.

Kolko, J. D. (2009). The effects of mobile phones and hands-free laws on traffic fatalities. The B.E. Journal of Economic Analysis \& Policy 9 (1 Contributions).

Lee, D. S. and T. Lemieux (2010). Regression discontinuity designs in economics. Journal of Economic Literature 48, 281-355.

Lissy, K. S., J. T. Cohen, M. Y. Park, and J. D. Graham (2000, July). Cellular phone use while driving: Risks and benefits. Technical report, Boston MA: Harvard Center for Risk Analysis. 
Nikolaev, A. G., M. J. Robbins, and S. H. Jacobson (2010). Evaluating the impact of legislation prohibiting hand-held cell phone use while driving. Transportation Research Part A 44, 182-193.

Redelmeier, D. A. and R. J. Tibshirani (1997). Association between cellular-telephone calls and motor vehicle collisions. New England Journal of Medicine 336(7), 453-458.

Redelmeier, D. A. and M. C. Weinstein (1999). Cost effectiveness of regulations against using a cellular telephone while driving. Medical Decision Making 19(1), 1-8.

Strayer, D. L., F. A. Drews, and D. J. Crouch (2006). A comparison of the cell phone driver and the drunk driver. Human factors $48(2), 381$.

Strayer, D. L., F. A. Drews, and W. A. Johnston (2003). Cell phone-induced failures of visual attention during simulated driving. Journal of Experimental Psychology: Applied 9(1), $23-32$.

Strayer, D. L. and W. A. Johnston (2001). Driven to distraction: Dual-task studies of simulated driving and conversing on a cellular telephone. Psychological Science 12(6), $462-466$. 


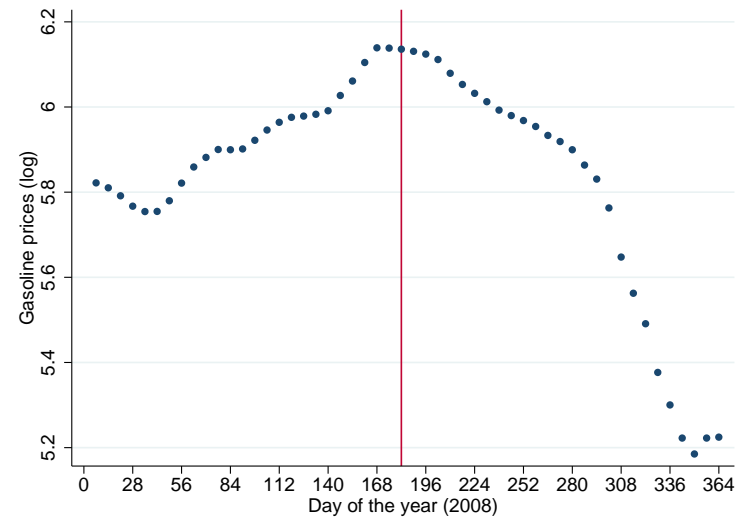

a) gas prices

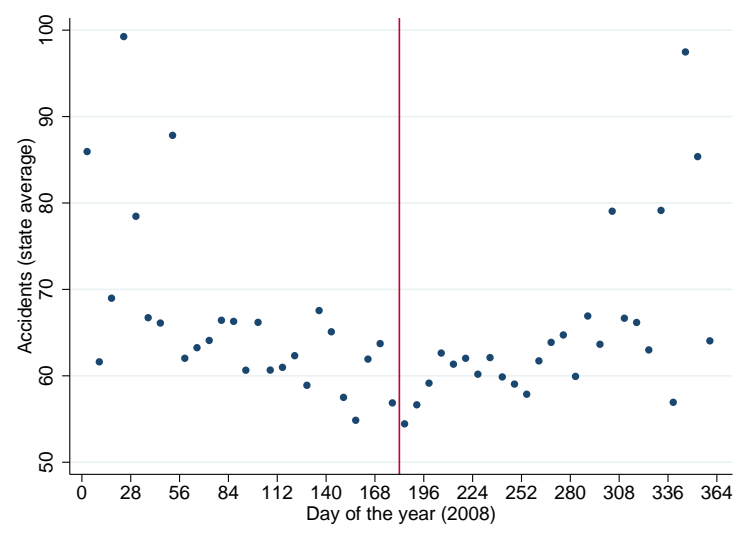

c) average collisions

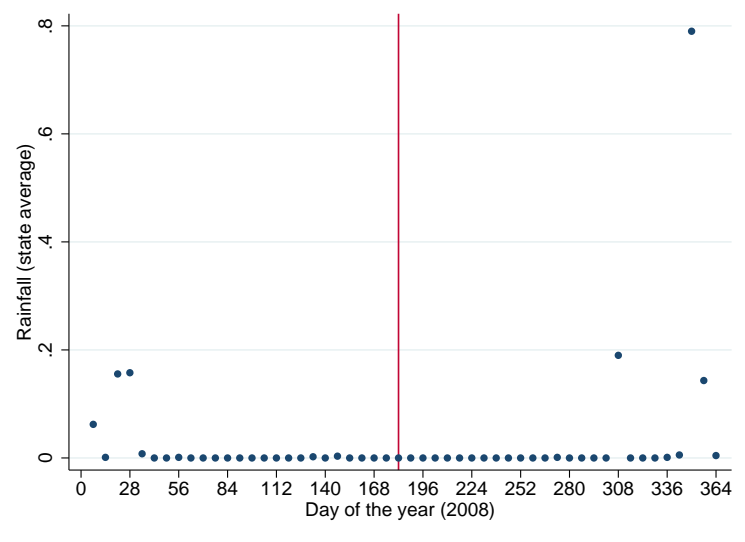

b) rainfall

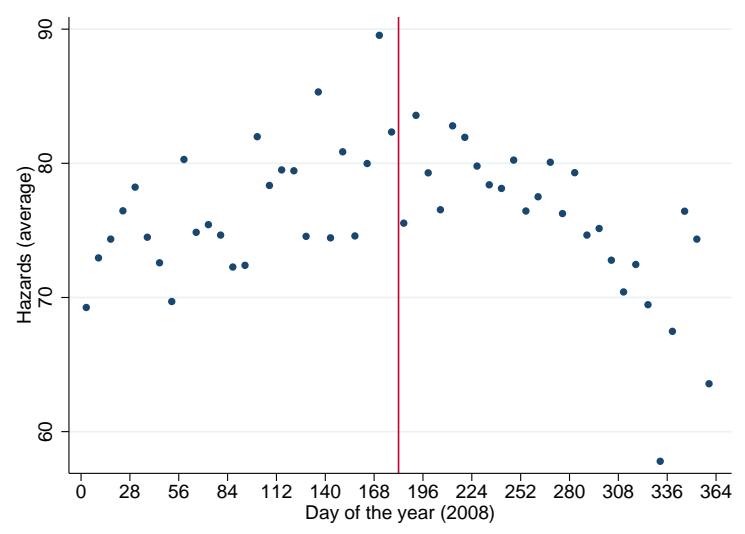

d) average hazards

Figure 1: Gas prices, rainfall, average collisions, average hazards 


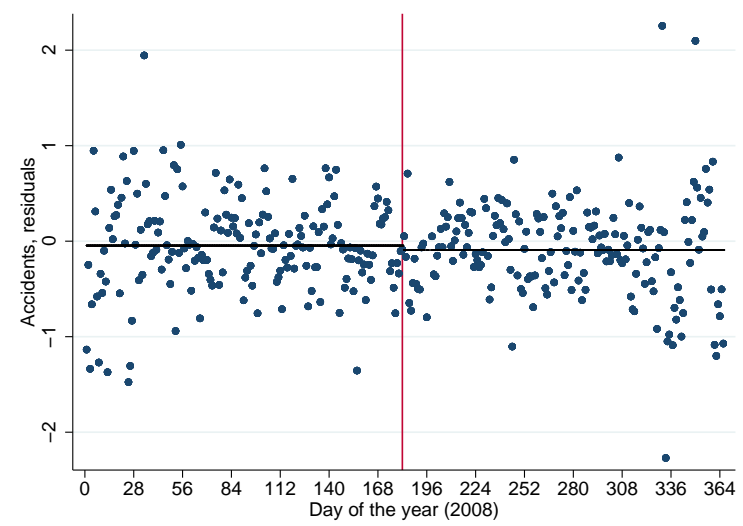

a) constant

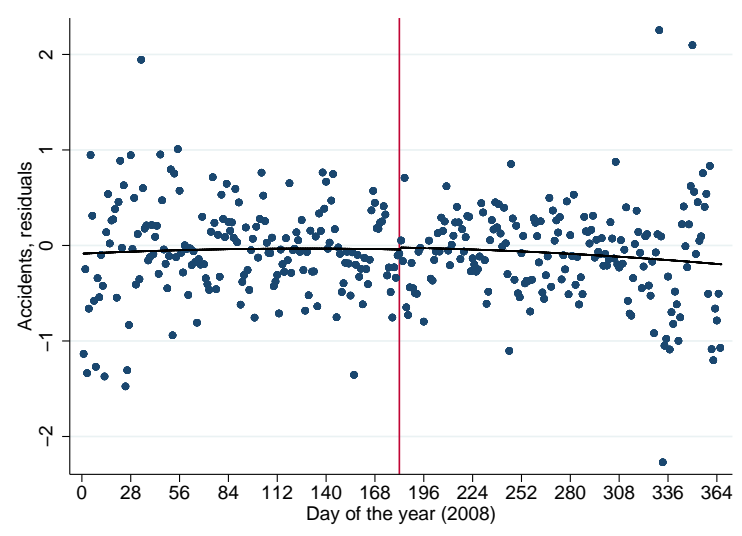

c) quadratic

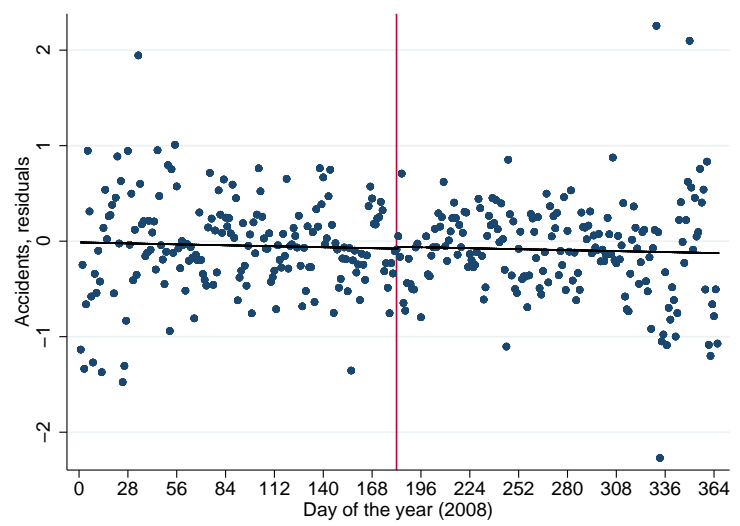

b) linear

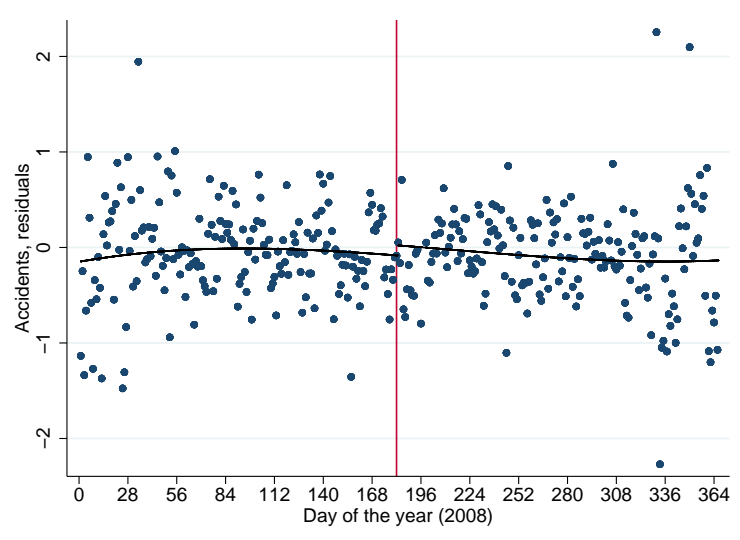

d) $c u b i c$

Figure 2: Residuals: Mean daily accidents, polynomial time trend 
Table 1: Summary Statistics

\begin{tabular}{lccccc}
\hline \hline & Mean & $\begin{array}{c}\text { Standard } \\
\text { Deviation }\end{array}$ & Minimum & Maximum & Major City \\
\hline Accidents & 65.93 & 65.31 & 5 & 719 & - \\
Hazards & 76.05 & 67.28 & 7 & 361 & - \\
Rainfall & 0.04 & 0.18 & 0 & 2.56 & - \\
Gas Price & 356.75 & 75.15 & 178.60 & 463.60 & - \\
\hline D3 accidents & 35 & 14 & 5 & 113 & Sacramento \\
D4 accidents & 113 & 36 & 38 & 408 & San Francisco \\
D5 accidents & 21 & 8 & 6 & 86 & Santa Barbara \\
D6 accidents & 26 & 9 & 8 & 108 & Fresno \\
D7 accidents & 210 & 69 & 66 & 719 & Los Angeles \\
D8 accidents & 65 & 27 & 24 & 328 & Riverside \\
D10 accidents & 21 & 7 & 5 & 61 & Stockton \\
D11 accidents & 48 & 26 & 19 & 268 & San Diego \\
D12 accidents & 52 & 21 & 12 & 224 & Irvine \\
\hline Note: Accidents, hazards, and rainfall levels are daily, gasoline prices are weekly. Rainfall is \\
reported in inches; gasoline prices are report in cents.
\end{tabular}


Table 2: Pre-ban and post-ban comparison of summary statistics

\begin{tabular}{lcc}
\hline \hline & Pre-ban mean & Post-ban mean \\
\hline Accidents & 66.71 & 65.15 \\
Hazards & 76.88 & 75.21 \\
Rainfall & 0.05 & 0.03 \\
Gas Price & 373.69 & 339.72 \\
\hline D3 accidents & 35.73 & 35.40 \\
D4 accidents & 113.63 & 113.96 \\
D5 accidents & 20.02 & 21.13 \\
D6 accidents & 25.12 & 27.09 \\
D7 accidents & 214.66 & 206.25 \\
D8 accidents & 67.89 & 62.90 \\
D10 accidents & 20.85 & 20.61 \\
D11 accidents & 49.70 & 47.54 \\
D12 accidents & 52.75 & 51.46 \\
\hline Note: Accidents, hazards, and rainfall levels are daily, gas prices are \\
weekly.
\end{tabular}


Table 3: Estimates of the effect of cell phone ban on accidents in California

\begin{tabular}{lcccccc}
\hline \hline Window & $1 / 1-12 / 31$ & $4 / 1-9 / 30$ & $6 / 1-7 / 31$ & $1 / 1-12 / 31$ & $1 / 1-12 / 31$ & $1 / 1-12 / 31$ \\
\hline Ban & -0.015 & 0.001 & 0.007 & 0.004 & $0.039^{*}$ & 0.010 \\
& $(0.009)$ & $(0.010)$ & $(0.018)$ & $(0.017)$ & $(0.019)$ & $(0.021)$ \\
Rainfall & $1.593^{* *}$ & $6.172^{* *}$ & $-36.441^{* *}$ & $1.582^{* *}$ & $1.596^{* *}$ & $1.585^{* *}$ \\
& $(0.098)$ & $(1.371)$ & $(11.063)$ & $(0.098)$ & $(0.099)$ & $(0.098)$ \\
Rainfall & $-0.586^{* *}$ & $-13.560^{* *}$ & $1771.468^{* *}$ & $-0.582^{* *}$ & $-0.584^{* *}$ & $-0.579^{* *}$ \\
& $(0.061)$ & $(4.486)$ & $(728.364)$ & $(0.061)$ & $(0.062)$ & $(0.061)$ \\
Gasoline price & $-0.151^{* *}$ & $-0.234^{* *}$ & $0.654^{*}$ & $-0.162^{* *}$ & $-0.342^{* *}$ & $-0.550^{* *}$ \\
& $(0.021)$ & $(0.072)$ & $(0.324)$ & $(0.023)$ & $(0.065)$ & $(0.114)$ \\
Holidays & $-0.155^{* *}$ & $-0.134^{*}$ & $-0.355^{* *}$ & $-0.156^{* *}$ & $-0.151^{* *}$ & $-0.150^{* *}$ \\
& $(0.038)$ & $(0.064)$ & $(0.084)$ & $(0.038)$ & $(0.038)$ & $(0.038)$ \\
& & & & & & \\
Observations & 3266 & 1583 & 504 & 3266 & 3266 & 3266 \\
\hline Time trend & none & none & none & linear & quadratic & cubic \\
DOW FE & Yes & Yes & Yes & Yes & Yes & Yes \\
District FE & Yes & Yes & Yes & Yes & Yes & Yes \\
\hline
\end{tabular}

Note: Dependent variable: Daily accidents across California. This table presents results from 6 separate regressions.

The values reported for each estimation are the coefficients on the regressors and their robust standard errors (in parentheses). In the first three columns, the coefficients and standard errors are estimated without a time trend and with varying bandwidths. In the last three columns, the coefficients and standard errors are estimated with varying time trends over the entire data set. * indicates 5 percent significance and ${ }^{* *}$ indicates 1 percent significance. 
Table 4: Estimates of the effect of cell phone ban on accidents in California: Local methods

\begin{tabular}{lcccc}
\hline \hline & \multicolumn{4}{c}{ Bandwidth } \\
Kernel & $1 / 1-12 / 31$ & $4 / 1-9 / 30$ & $5 / 1-8 / 31$ & $6 / 1-7 / 31$ \\
\hline Rectangular & -0.014 & 0.001 & 0.015 & -0.007 \\
& $(0.009)$ & $(0.010)$ & $(0.013)$ & $(0.018)$ \\
Triangular & -0.012 & 0.002 & -0.001 & -0.032 \\
& $(0.008)$ & $(0.012)$ & $(0.014)$ & $(0.020)$ \\
Epanechikov & -0.013 & 0.004 & 0.003 & -0.033 \\
& $(0.008)$ & $(0.011)$ & $(0.014)$ & $(0.019)$ \\
Gaussian & -0.014 & 0.002 & 0.011 & -0.014 \\
& $(0.008)$ & $(0.011)$ & $(0.013)$ & $(0.018)$
\end{tabular}

$\begin{array}{lllll}\text { Observations } & 3266 & 1583 & 1008 & 504\end{array}$

Note: Dependent variable: Daily accidents across California. This table presents results from 16 separate regressions. The values reported for each estimation are the coefficient on the policy variable (cell phone ban) and the robust standard error (in parentheses). All regressions include controls for rainfall, gas prices (logged), holidays, days-of-week and includes district fixed effects. * indicates 5 percent significance and $* *$ indicates 1 percent significance. 
Table 5: Sensitivity Analysis

\begin{tabular}{|c|c|c|c|c|}
\hline $\begin{array}{l}\text { Remove three weeks } \\
\text { from center }\end{array}$ & $\begin{array}{l}-0.011 \\
(0.010)\end{array}$ & $\begin{array}{c}0.009 \\
(0.021)\end{array}$ & $\begin{array}{l}0.062^{*} \\
(0.026)\end{array}$ & $\begin{array}{c}0.036 \\
(0.030)\end{array}$ \\
\hline $\begin{array}{l}\text { Remove three weeks } \\
\text { Pre-Ban }\end{array}$ & $\begin{array}{l}-0.015 \\
(0.010)\end{array}$ & $\begin{array}{c}0.012 \\
(0.022)\end{array}$ & $\begin{array}{c}0.077^{* *} \\
(0.028)\end{array}$ & $\begin{array}{c}0.046 \\
(0.030)\end{array}$ \\
\hline $\begin{array}{l}\text { Remove three weeks } \\
\text { Post-Ban }\end{array}$ & $\begin{array}{l}-0.007 \\
(0.010)\end{array}$ & $\begin{array}{c}0.027 \\
(0.020)\end{array}$ & $\begin{array}{l}0.078 * * \\
(0.024)\end{array}$ & $\begin{array}{l}0.061^{*} \\
(0.030)\end{array}$ \\
\hline Observations & 3078 & 3078 & 3078 & 3078 \\
\hline Time Trend & None & Linear & Quadratic & Cubic \\
\hline \multicolumn{5}{|c|}{$\begin{array}{l}\text { Note: Dependent variable: Daily accidents across California. This table represents } \\
\text { results from } 12 \text { separate regressions. The values reported for each estimation are } \\
\text { the coefficient on the policy variable and the robust standard error (in parentheses). } \\
\text { All regressions include controls for rainfall, gas prices (logged), holidays, days-of- } \\
\text { week, and district effects. In the first panel, three weeks of data was removed from } \\
\text { the center. In the second panel, three weeks of data was removed just prior to } \\
\text { the start of the Ban. In the third panel, three weeks of data was removed just } \\
\text { after the start of the Ban.* indicates } 5 \text { percent significance, }{ }^{* *} \text { indicates } 1 \text { percent } \\
\text { significance. }\end{array}$} \\
\hline
\end{tabular}

